OPEN ACCESS

Edited by:

Miguel Ferrer,

Consejo Superior de Investigaciones

Cientificas (CSIC), Spain

Reviewed by:

Alvaro Soutullo,

Universidad de la República, Uruguay

Joan Real,

University of Barcelona, Spain

*Correspondence:

Iñigo Zuberogoitia

zuberogoitia@icarus.es

tThese authors have contributed equally to this work

Specialty section:

This article was submitted to

Conservation and Restoration

Ecology,

a section of the journal

Frontiers in Ecology and Evolution

Received: 20 January 2021 Accepted: 05 July 2021

Published: 27 July 2021

Citation:

Zuberogoitia I, Morant J,

González-Oreja JA, Martínez JE,

Larrinoa M, Ruiz J, Aginako I,

Cinos C, Díaz E, Martínez $F$

Galarza A, Pérez de Ana JM, Vacas $G$,

Lardizabal B, Iriarte I and Zabala $J$

(2021) Management Actions Promote

Human-Wildlife Coexistence in Highly

Anthropized Landscapes: The Case

of an Endangered Avian Scavenger.

Front. Ecol. Evol. 9:656390.

doi: 10.3389/fevo.2021.656390

\section{Management Actions Promote Human-Wildlife Coexistence in Highly Anthropized Landscapes: The Case of an Endangered Avian Scavenger}

\author{
Iñigo Zuberogoitia ${ }^{1,2 * t}$, Jon Morant ${ }^{2 t}$, José Antonio González-Oreja ${ }^{3}$, \\ José Enrique Martínez ${ }^{4}$, Mikel Larrinoa ${ }^{5}$, Julio Ruiz ${ }^{5}$, Igor Aginako ${ }^{5}$, Cristina Cinos ${ }^{5}$, \\ Eneko Díaz ${ }^{5}$, Fran Martínez ${ }^{5}$, Aitor Galarza ${ }^{5}$, Juan Manuel Pérez de Ana ${ }^{5}$, Gorka Vacas ${ }^{5}$, \\ Beñat Lardizabal ${ }^{5}$, Iñigo Iriarte ${ }^{5}$ and Jabi Zabala ${ }^{6}$ \\ 'Estudios Medioambientales Icarus S.L. C/ San Vicente, Bilbao, Spain, ${ }^{2}$ Department of Ornithology, Aranzadi Sciences \\ Society, Donostia-San Sebastián, Spain, ${ }^{3}$ Facultad de Ciencias Biológicas, Benemérita Universidad Autónoma de Puebla, \\ Puebla, Mexico, ${ }^{4}$ Bonellis Eagle Study and Conservation Group, Murcia, Spain, ${ }^{5}$ Departamento de Sostenibilidad y Medio \\ Natural, Diputación Foral de Bizkaia, Bilbao, Spain, ${ }^{6}$ Department of Zoology and Animal Cell Biology, University of the \\ Basque Country, UPVIEHU, Bilbao, Spain
}

Anthropized landscapes are characterized by various human activities related to resource extraction, recreational activities, and urbanization, among others. Conservation of species living in such landscapes is challenging due to the lack of compatibility between wildlife and human needs, which can create win-lose scenarios for target species. Therefore, adequate management practices are necessary to reduce conflicts and promote coexistence between wildlife and human beings. Here, we test the effectiveness of management measures on the productivity of an Egyptian vulture population living in an anthropized region of Northern Spain by using long-term monitoring data (2000-2020). During the first decade, we demonstrated that disturbance events negatively affected the species reproduction. Therefore, in 2010 we started a management plan in which we first established a basis for the species protection, and second we developed management actions to avoid or reduce the impact of potential disturbance events on the Egyptian vulture' breeding. We observed that almost half of the disturbances detected after the management was related to resource extraction activities such as forestry (40.6\%). Management measures effectively increased productivity (84 vs 137, chicks fledged successfully before and after, respectively) and the breeding success of the pairs in which the disturbances were detected and stopped (66.7\%) was much higher than those non-managed and non-stopped in time (17.4\%). Moreover, we estimated that 44 nestlings (32.1\%) would have died without management actions during the second decade. Overall, our work demonstrated that collaborative networks can design and implement effective management measures for endangered territorial species, taking 
into account all agents involved (policymakers, rangers, stakeholders, general public, and researchers) in the conservation area. Thereby, it alleviates conflicts in humandominated ecosystems and generates a balanced scenario that favors long-term sustainable human-wildlife coexistence.

Keywords: biodiversity monitoring, conservation conflicts, Egyptian vulture, human disturbances, effective conservation measures, landscape management

\section{INTRODUCTION}

As human population increases, so does the impact caused on ecosystems and species living on them (Venter et al., 2016). Currently, only $42-50 \%$ of the Earth's surface could be considered free or exhibiting low levels of human disturbances (Riggio et al., 2020). In fact, $20 \%$ of the planet's terrestrial surface is classified as built-up or cropland (Defourny et al., 2017), but only 15\% of Earth's land surface is formally under protection (UNEP-WCMC, IUCN, and NGS, 2019). This means that majority of the taxa are now living in environments under moderate and high human pressures (O'Bryan et al., 2020). Such environments, namely anthropized landscapes, are characterized by intense and abrupt land-use changes derived from different human activities (e.g., resource extraction activities, recreational activities, agriculture, hunting, among others) and urban development (Newbold et al., 2015). Therefore, the organisms inhabiting anthropized landscapes have had their behavior, physiology, phenology, and life history traits negatively altered (Gaynor et al., 2018; Sanders et al., 2020; Wilson et al., 2020), which can in the worst cases ultimately result in population declines and extinctions with severe ecological impacts (Wilson et al., 2020).

Management of threatened and endangered species requires decision making in the face of uncertainty (Runge, 2011). Complex management decisions necessitate a management approach that supports effective decision-making and incorporates practitioner knowledge changes as management progresses (Dreiss et al., 2017). Usually, management actions are based on measures in which actions focus only or mostly on target species and do not consider humans inhabiting the same areas. This leads to conservation conflicts in which one of the relevant parties is excluded from the conservation and management participatory processes (Redpath et al., 2013). Conservation in anthropized landscapes could be particularly challenging since it requires knowledge not only of the "how" and "where" some species thrive and persist but also of the social, cultural, and economic context themselves (Blackwell et al., 2016). However, in some cases, human intervention takes more weight at the time of reversing population declines or palliating the effects of different human impacts (Bolam et al., 2020). To improve conservation planning in such conditions or environments, both the spatial variation in causes generating the conflicts and the target species' particular requirements must be identified (Ferrier and Wintle, 2009). This holds especially true for territorial species with high ecological requirements and slow reproductive rates which are frequently on the brink of extinction and involved in most conservation conflicts (Ripple et al., 2014; van Eeden et al., 2018).

Raptors are declining quicker than other birds, with $52 \%$ of species in decline and $18 \%$ currently classified as threatened with extinction. Vultures, and particularly Old-World vultures, are by far the most threatened group within them, with 12 of 16 species listed as Endangered or Critically Endangered (McClure et al., 2018; BirdLife International, 2020; McClure and Rolek, 2020). Deliberate or unintentional poisoning events (Plaza et al., 2019; Aresu et al., 2020), conflicts with farmers depending on regional differences of livestock management (Margalida et al., 2014; Duriez et al., 2019), and low survival probability due to accidents with infrastructure, such as electrocution and collision with power lines and wind turbines (e.g., Donázar et al., 2002; Ogada et al., 2016; Badia-Boher et al., 2019; Arrondo et al., 2020) are among the main hazards for this avian group worldwide. Their particular biology and life history (delayed sexual maturity and low productivity, Donázar, 1993), together with the abovementioned threats, caused vulture populations to plummet worldwide (Ogada et al., 2012). This situation urged scientists to delineate priority areas for conservation based on specieslevel risk assessment (Santangeli et al., 2019). Nevertheless, problems identified at broad scales might not reflect local-level factors (Efrat et al., 2020). Vulture populations in Europe are threatened by several hazards, that greatly vary among socioeconomic and political situations of different countries or, even, within countries (see for example Olea and Mateo-Tomás, 2014). In highly anthropized landscapes, setting aside large areas of land for conservation might not be feasible due to intensive uses for recreational or economic activities. Further, usually there are areas or locations of high conservation value (e.g., nest sites, feeding sites) that are dispersed outside protected areas, often close to cities and villages, and subject to unique and variable pressures. These sites can support, altogether, a relevant part of the population and their dynamic management is needed to make conservation compatible with other uses, and enhance conservation efforts focused on protected areas. In order to improve conservation measures and reduce conservation conflicts, based on sound scientific evidence, the participation and coordination of authorities, managers, ecologists, and other social actors is needed (Redpath et al., 2013).

The Egyptian Vulture (Neophron percnopterus) is a mediumsized, long-lived, monogamous, scavenger (Ferguson-Lees and Christie, 2001). Western European mainland populations spend the winter (and usually their first year of life) in the sub-Saharan Sahel region (Phipps et al., 2019), although a non-migrant 
population was detected in South-western Spain (Morant et al., 2020a). It is listed as globally endangered due to severe declines experienced throughout its range (BirdLife International, 2020). This is a species with a slow life-history, showing deferred maturity, and low fecundity ( $0-2$ fledglings per breeding attempt; Serrano et al., 2021). They breed in cavities and on ledges on cliffs located in open landscapes, usually in rugged, arid regions (Donázar, 1993). Breeding pairs arrive from their winter grounds in Africa in late February and early March and remain in their territories until mid-September/October (Phipps et al., 2019). They generally reuse the same nest unless they are disturbed during sensitive phases, or the nest area is altered (Zuberogoitia et al., 2008; Morant et al., 2018).

The Egyptian vulture population in Biscay, northern Spain, is made up of 18-25 occupied territories. It occupies mountainous landscapes, far from towns and villages, where extensive cattle farming and timber extraction are the main economic activities. Breeding success and productivity in this population are affected by adverse weather conditions (mainly rainfall, Zuberogoitia et al., 2014), but mostly by disturbance derived from human activities (Zuberogoitia et al., 2008). In fact, the population suffered a severe decline in productivity during the first decade of 2000s, mainly due to the direct impact of recreational activities and forestry during the breeding period (see Zuberogoitia et al., 2008, 2014). In order to revert this situation, we started a management program in 2010 aimed at reducing the impact of human activities on Egyptian vultures' breeding success and hence, increasing population viability (Zuberogoitia et al., 2014). This program, which was ongoing at writing this paper, has been designed to reconcile conservation pactices that account for crucial species requirements with human activities (see, for instance, McCarthy and Possingham, 2007). In our study area, these activities include outdoor sports, recreational activities, road-works, and impacts associated with quarries, among others. In this study, we show how management measures have successfully helped to solve conservation conflicts in landscapes subjected to several human activities. Using longterm monitoring data (2000-2020), we test the effectiveness of management measures on the Egyptian vulture population inhabiting a highly human-modified area. Here we assess whether these management actions on breeding territories subjected to various disturbance regimes have effectively benefited the study population. Finally, we discuss future directions and challenges to mitigate vulture-human conservation conflicts.

\section{MATERIALS AND METHODS}

\section{Study Area}

The study was conducted in Biscay (northern Spain; area $2,384 \mathrm{~km}^{2}$; coordinates from $43^{\circ} 11^{\prime} 00^{\prime \prime}$ to $43^{\circ} 12^{\prime} 70^{\prime \prime} \mathrm{N}$ and from $3^{\circ} 12^{\prime} 70^{\prime \prime}$ to $2^{\circ} 13^{\prime} 10^{\prime \prime} \mathrm{W}$ ). It has an Atlantic climate and mild temperatures with a thermic oscillation of $12^{\circ} \mathrm{C}$ from the coldest to the hottest months and 1,200-2,000 mm of rainfall distributed throughout the year (Euskalmet.eus, 2021). The landscape is mountainous and densely populated (520 inhabitants $/ \mathrm{km}^{2}$; Eustat.eus, 2020), with extensive urban and industrial areas, mainly located in valley floors and on the gentler slopes, while mountain areas support semi-natural landscapes and wildlife. Overall, $79 \%$ of the area is dedicated to forestry (Euskadi.eus, 2019). Forestry plantations (Pinus radiata and Eucalyptus spp.) have become widespread in the last 80 years, gradually replacing grazing land for extensively reared livestock, traditional agricultural activities, as well as a few remnants of native forest.

\section{Field Work and Data Collection}

Annually, between 2000 and 2020, from February to September, we surveyed and monitored known and possible breeding areas to determine the location of all territories and nests of Egyptian vultures (between a minimum of 18 and a maximum of 25 territories per year). From 2000 to 2020, we identified 25 different breeding territories and monitored 86 nest sites within them (mean \pm s.d., $3.44 \pm 1.61$ nest sites per territory, and range $=1-7)$, that were used at least once in these 21 years. Although Egyptian vultures had several nest sites in each territory, they normally used one or two as preferred nests (Morant et al., 2020b). We examined changes in occupancy, breeding parameters (breeding success and productivity), and population trends (number of territories and breeding pairs per year). We used $20 \times 60$ telescopes to observe nests from vantage points located far enough to preclude disturbing the breeders (mean distance: $c a .1,000 \mathrm{~m}$; range: $442-2,826 \mathrm{~m}$; Zuberogoitia et al., 2008).

Monitoring also included the assessment of disturbances within breeding territories from the last weeks of February to middle September. Disturbance variables were measured in a $1,000 \mathrm{~m}$ radius around the occupied nest sites (Zuberogoitia et al., 2008; Morant et al., 2020b). On average (s.d.), 13 (3.7) experienced observers spent 265.5 (77.1) survey hours in 107.4 (162.2) survey days per year. Human activities observed in the vicinity of the nest site that could disturb vultures during reproduction were: forestry works (cuts, clear-cuts, afforestation, and opening of new forest tracks); operation of quarries; public works (building or maintenance of roads, electric lines, and gas pipelines); cars, motorcycles and tractors passing or parking in the vicinity of the nest sites; climbers, hikers, mountain bikers, helicopters, paragliders, photographers, and birdwatchers; illegal hunting; outdoor sports (pedestrian and mountain bike racings); and fire. We considered the alert behavior (when a at least one vulture was prevented from entering its nest and flew around the cliff in apparent uneasiness, Zuberogoitia et al., 2008) and the reproductive parameters (incubation, changeover rate, feeding rate, and others, Morant et al., 2019) to asses the intensity of disturbing events. According to their duration and frequency, disturbances were classified into: (1) low: low level, specific, non-recurring disturbances (i.e., occasionally detected and did not cause an evident alert behavior and did not alter the normal reproductive behavior of the Egyptian vultures; e.g., people practicing sports or forestry and farming works for short periods (less than 1 or $2 \mathrm{~h}$ ) and far from the nest site ( $>600 \mathrm{~m}$, considering the $1 \mathrm{~km}$ radius); (2) medium: one-off high level or medium-level disturbances (i.e., when disturbance duration extended for several hours; e.g., multitudinous races during 
one whole day, large vehicles, or machines working for several hours); and (3) high: chronic and high-level disturbances (i.e., detected through all day, or during several days, or when the effect was permanent; e.g., forestry activities, works related to the construction of new infrastructures and actions which produced direct disturbance, permanent alert behavior of the adults and negative changes in the expected rate of reproductive parameters, during the entire activity period). High-level disturbances can carry on temporal (e.g., machines and vehicles working) or permanent habitat changes (e.g., opening of new roads, trails and paths close to nests, or forest cuts which eliminate protection patches of vegetation around the nests) and, consequently, they can influence nesting in the future (Morant et al., 2018). Further, considerable modification of areas surrounding nesting sites (permanent habitat changes), even if they take place during the winter -when breeders are absent from the area-, can push adults to move to alternative, less preferred or lower quality sites, resulting in higher chances of failure in subsequent nesting events (Morant et al., 2018).

\section{Establishing the Basis for the Species Protection}

In 2010, the local government, Biscay County Council (hereafter, BCC), implemented a series of measures to address the activities that most often and seriously interfered with the Egyptian vultures' breeding, as identified in the 2000-2009 period. These included: (a) A climbing management plan for wildlife conservation (Web.bizkaia.eus, 2010) ${ }^{1}$. In this document, authorities regulated sites and periods in which climbing is allowed. Further, this plan is continuously updated and adapted to changes in nest site location of target species, mainly Egyptian vultures. (b) The BCC also implemented an inter-department management plan to enhance coordination with the forestry department and reduce the impact of forestry activities on wildlife, especially on Egyptian vultures. The main objective of this plan is to prevent forestry works and related activities around nest sites during the breeding period (from 1st March to the end of September) and to conserve local landscape around nesting sites. Finally, (c) from 2011 onward, the BCC started regulating outdoor sports, mainly outdoor races (pedestrian, bike, and motorbike). These management actions were legally regulated in 2018 (Bizkaia, 2021a,b). Every year, outdoors racings must apply for a permission and are evaluated by wildlife managers to verify that routes avoid commonly used nest sites and nesting territories of Egyptian vultures during the breeding season.

In 2015, the BCC passed the Management Plan of Vultures in the Basque Country (Bizkaia, 2021c). The main goals of that document are: (1) To assure the protection of Special Interest Areas (SIAs: areas where abundance and diversity of vulture species are fundamental for the long-term conservation of their populations) and Critical Areas (CAs: vital areas for Egyptian vulture survival and conservation); (2) to mitigate the nonnatural mortality causes; and (3) to reduce human disturbances in the breeding, foraging and roosting areas. The Plan establishes critical periods for the species, from the 1st March to 15th

\footnotetext{
${ }^{1}$ web.bizkaia.eus
}

September. The Plan also establishes general guidelines for Environmental Impact Assessments to assure the conservation of the target species through habitat retention and restoration, as well as monitoring breeding success.

Overall, BCC environmental managers assessed 5,095 files from 2010 to 2019, where the potential disturbance events on Egyptian vulture breeding territories was evaluated (Figure 1). Managers reported on the activities and allowed, denied or delayed them according to the potential impact on Egyptian vulture breeding performance. The potential impact of submitted activities was assessed considering (1) the number of nest sites known within that territory, (2) the frequency of use of the potentially affected nest site and when it was last used, (3) the distance and the position of the activity relative to the nest site (e.g., in front, at side, or back) of the intervention, and the presence of a buffer area (e.g., forest patch) between the nest site and the alteration area, and (4) whether other alterations were recently made within the $1 \mathrm{~km}$ radius and the possibility of synergistic effects with previous activities. In any case, any activity that could generate a disturbance within the $1 \mathrm{~km}$ radius around the 86 known nest sites must finish before the end of February, when Egyptian vultures arrive at our study area.

\section{Management Action Plan for the Species Conservation}

In 2010, BCC environmental managers started applying management actions and a special monitoring protocol for preventing human disturbances in Egyptian vulture breeding

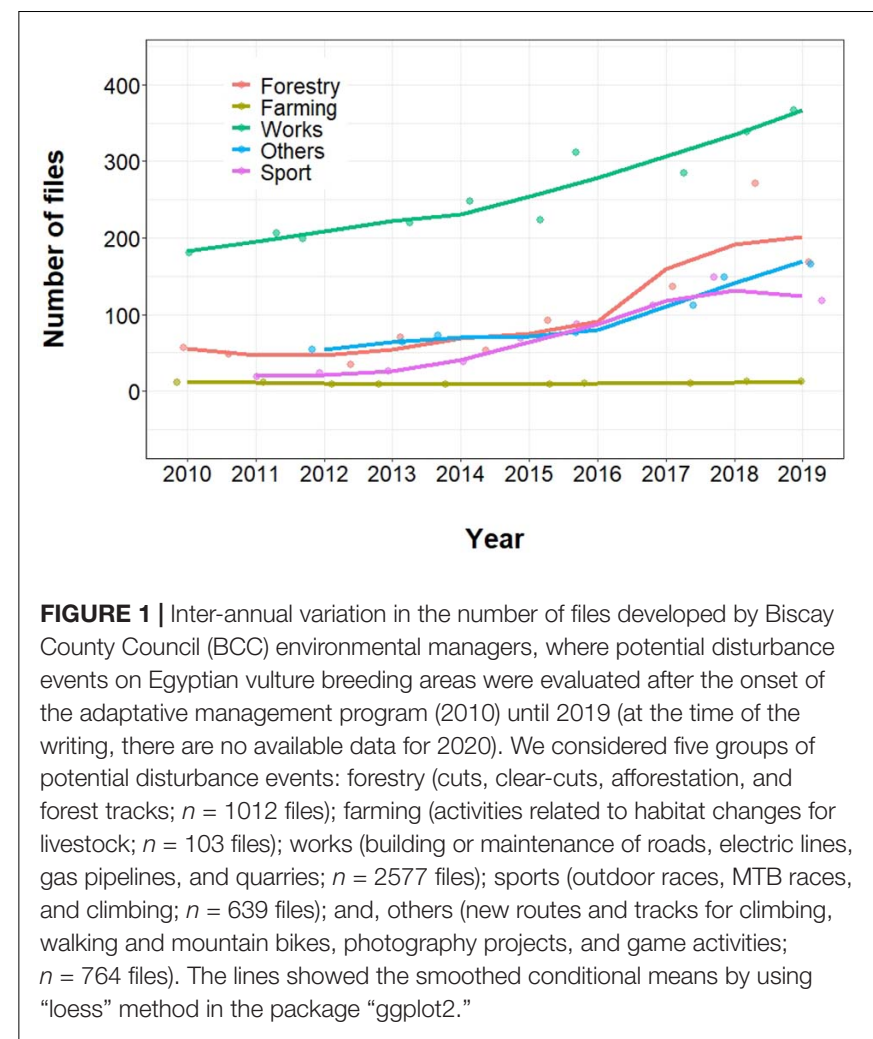


territories. Annually, before the arrival of this migratory species from Africa to the study area, the first management measure consisted of preventing habitat alterations within $1 \mathrm{~km}$ of each of the 86 nest sites. Human activities that could potentially modify landscape and vegetation around nest sites (e.g., opening tracks or falling timber plots; see Morant et al., 2018 for details on such activities) must be approved by BCC environmental managers following the basis for the species protection.

After the arrival of the species to the study area, ecologists and rangers systematically monitored Egyptian vultures (Morant et al., 2020b). The first individuals usually arrive during the third week of February. The breeding cycle of Egyptian vultures starts with nest repair and nest building and courtship; both activities take place simultaneously and start 25 days before the onset of incubation (Morant et al., 2019). At this time, mates typically use a resting site close to the selected nest site. Therefore, we could reliably identify the breeding site at the end of March. In the study area, incubation starts, on average, on April 17th (Morant et al., 2019). However, the activity restrictions around all known nest sites used during the last two decades lasted until assuring incubation onset and the selected nest site. Afterward, managers authorized those activities that had been stopped in the nonselected nest sites while the activity restrictions continued around the active nest sites.

Then, from the onset of incubation until offspring fledge, ecologists and rangers monitored reproduction of all the territories. In this period, no disturbance events are expected to occur in the nesting areas. Every non-authorized disturbing activity detected within the $1 \mathrm{~km}$ radius of the active nest sites previously defined was immediately reported to BCC environmental managers, the potential hazard to the species analyzed by managers, in conjunction with ecologists if required, and stopped immediately if deemed potentially hazardous to the species. Some disturbance events were successfully managed and quickly stopped before causing any obvious impact, but others could not be managed and stopped in time to avoid deleterious effects on the breeding territory. Low-level disturbance events were particularly difficult to manage in time to avoid negative effects. Management actions were then focused to prevent similar events (e.g., warning signs and awareness campaigns). In particular cases, if a disturbing activity had to be carried on by major force reasons, intensive monitoring of the pair was conducted, and some activities and their timing were consequently regulated. Normally, no disturbing activity was allowed during incubation and the first weeks of life of nestlings. During this time, ecologists and rangers analyzed the breeding behavior of the target pair according to the patterns described by Morant et al. (2019), and stopped any disturbance events that affected the behavior and could cause the loss of the clutch or nestlings.

The potentially disturbing activities were only allowed once the post-fledgling dispersal began, the exact date of which varies among pairs from the first weeks of August to the end of September, or when natural failure of the reproduction event was detected (mainly due to intensive and continuous precipitations, see Zuberogoitia et al., 2014). Thus, the date on which disturbances were allowed was individually tailored to each breeding attempt.

\section{Data Analysis}

In order to assess the effectiveness of management actions over the breeding territories, we ran Generalized Linear Mixed Models (GLMMs) fitted with the Laplace approximation (Bolker et al., 2009), with productivity (number of successfully fledged offspring; 0, 1, or 2) as the response variable. We favored a Gaussian error distribution over a Poisson one since the variance to mean ratio clearly departed from 1 (e.g., in the global model, $\bar{x}=0.647, \sigma^{2}=0.475$ ) and data were righttruncated. Further, the Gaussian distribution has been shown to perform well with small count data such as clutch sizes (see McDonald and White, 2010 for more details). Territory and nest were entered as random factors (the second nested within the first), to account for the lack of independence of data due to the reuse of the same nests throughout different years. In a previous work (Zuberogoitia et al., 2014), we built a model selection using three subsets of predictor variables: nest site variables, weather variables, and disturbance variables. The disturbance model (only the disturbance variable) was the best model among the model selection procedure carried out by Zuberogoitia et al. (2014). Therefore, we considered disturbance as predictor in our model, and we also included management $(0=$ before, $1=$ after management) and the interaction between disturbance and management as fixed factor variables. The interaction between the two factors allowed us to investigate the effect of disturbance regimes in species productivity and to assess the efficiency of the management actions. It is important to remark here that all disturbances recorded during the second decade and coded here as "after management" were real disturbances that were taking place, or about to be started (for instance, employers and machines deployed in the field, and just prepared to start working), when detected and stopped immediately or in a few hours of being detected. Therefore, we assumed they were real threats that, if unmanaged, would have provoked similar effects on breeding success as they really had in the previous decade.

In order to assess the contribution of our management approach to population dynamics, we estimated the number of fledglings that would have been lost without it. For this end, we considered the average predicted productivity for disturbances of medium (0.07 fledglings per breeding pair) and high (0.007 fledglings per breeding pair) level obtained from the model, considering data of 2000-2009. Then, we took into account cases of high and medium-level disturbances that were successfully managed in the second decade, and selected only those that raised ( 1 or 2 ) fledglings. For these nests we changed the actual, observed number of fledglings for the average expected in case we had not successfully managed the disturbances.

All statistical analyses were performed using the $\mathrm{R}$ software ( $\mathrm{R}$ 4.0.2). GLMMs were run by using the "lmer" function implemented in the package "lme4" (Bates et al., 2012). We estimated the marginal and conditional variance explained by our model by using the "rsquared" function implemented in the package "piecewiseSEM" (Lefcheck, 2015). Finally, we visually inspected the normality of the residuals of our model by using 
the "ggresid" pannel function implemented in the package "ggresidpannel" (Goode and Rey, 2019). P-values were estimated by using the package "afex" (Singmann et al., 2021). Model performed well according to the distribution of the residuals. All the figures were done by using the package "ggplot2" (Wickham, 2016). Mean values are reported with $( \pm)$ their standard deviation. Statistical significance was set at $P<0.05$.

\section{RESULTS}

The management actions significantly reduced the impact of disturbances on Egyptian vulture breeding success. Before the implementation of management actions, we monitored 207 breeding attempts of Egyptian vultures, 136 of which started reproduction (i.e., at least one egg was laid) and produced 87 fledglings (Figure 2). In this period, 2000-2009, we detected a significant negative effect of medium and highlevel disturbances on productivity (Tables 1, 2 and Figures 3A,B). After the implementation of management actions, 20102020, we monitored 218 breeding attempts, 185 of which started reproduction and produced 134 fledglings (Figure 2). In the first decade, the number of pairs that did not breed $(7.1 \pm 1.9$ per year) was more than twice that detected in the second decade $(3.0 \pm 2.0$ per year; $t$ student $=6.25, P<0.001)$. Moreover, after the implementation of the management protocol, we detected 148 events related to disturbances that could affect Egyptian vulture breeding success: 17 low-level disturbances, 59 medium-level disturbances, and 72 high-level disturbances (Table 1). From them, $11.7 \%$ of the low-level, $47.5 \%$ of the medium-level, and $65.3 \%$ of the high-level disturbances were managed and stopped.

In the managed period, almost half of the disturbance events detected after the management actions were implemented were related to forestry practices of which $58.9 \%$ of the detected cases were managed and stopped (Table 3 ). The breeding success (percentage of pairs that successfully breed per the number of pairs that start reproduction) in the managed cases (66.7\%) was ca. 4 times higher than those that could not be managed and stopped in time (17.4\%). Moreover, we detected the shifts in nest sites in two managed cases and five in non-managed cases. Activities related to works and quarries were previously analyzed and protocolized, and most of them were correctly managed, showing a high rate of breeding success (Table 3). Outdoor sports, mainly individual or small group activities, people walking in the field or other activities (e.g., illegal hunting or fires, photographers, and maintenance works in buildings), were difficult to detect and to manage in time to avoid deleterious effects on reproduction (Table 3 ).

During the implementation of management actions, we detected a statistically significant reduction in the effect of medium and high-level disturbances on productivity (Table 2). Still, there were differences in the productivity of those territories affected by these medium and high-level disturbances and those affected by low-level disturbances (Figures 3A,C). In this case, the marginal variance was only $2.4 \%$. In the managed period, we did not avoid 31 medium-level disturbances of 28 breeding

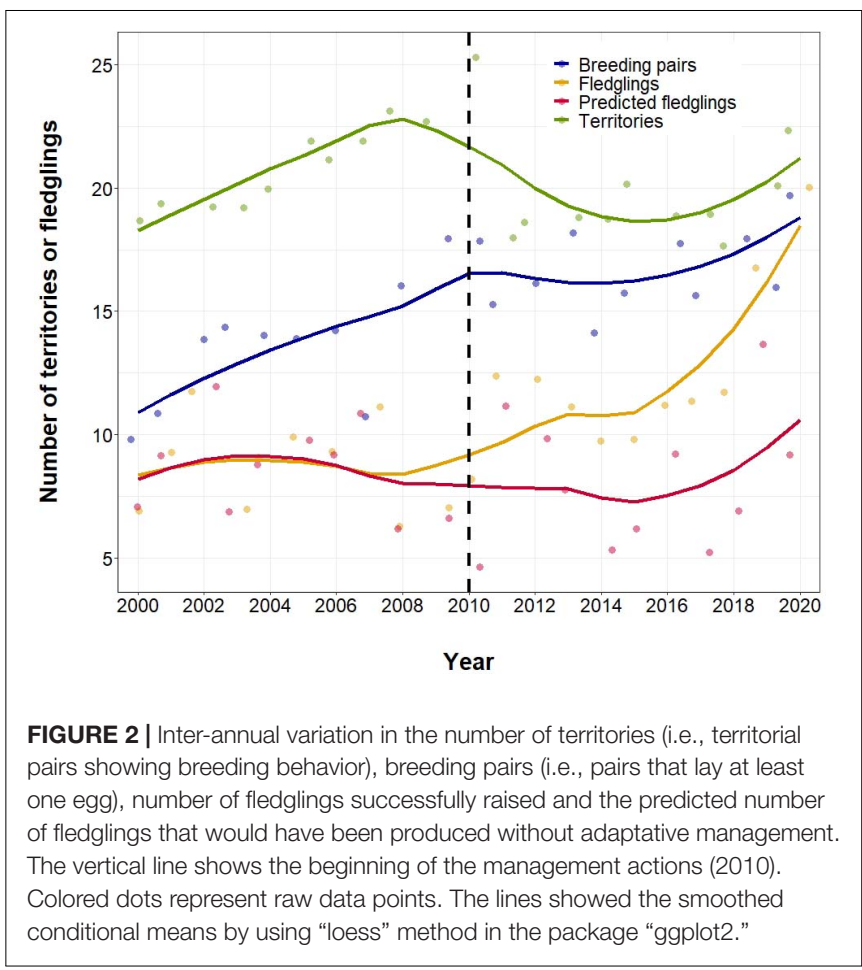

attempts that finally produced nine fledglings ( 0.32 fledglings per breeding pair) and 25 high-level disturbances of 17 breeding attempts that finally produced three fledglings ( 0.18 fledglings per breeding pair). Taking into account the results of the 21 monitoring years (global period), we found significant differences considering the interactions between the four disturbance types and managed actions (Table 2 and Figure 3 ).

Considering the average predicted productivity, 44 nestlings $32.1 \%$ of the chicks raised in the 2010-2020 period) would have died if management actions had not been implemented (Figure 2).

Overall, $72 \%$ of breeding attempts that suffered disturbances failed to breed prior to the implementation of management (2000-2009), whereas, under management (2010-2020) the number of failures due to disturbances affected $49 \%$ of the breeding attempts.

\section{DISCUSSION}

The long-term monitoring of the Egyptian vulture population in the study area allowed us to identify the effects of one particular threat: the effects of disturbance on breeding success and productivity (Zuberogoitia et al., 2008; Morant et al., 2018). We also studied the effectiveness of conservation measures taken to revert these effects (Zuberogoitia et al., 2014). The number of studies identifying threats and assessing the effectiveness of management measures on species, populations, and ecosystems has notably increased during the last decades (Richardson et al., 2020). Recently, Bolam et al. (2020) showed that conservation actions prevented 21-32 bird and 7-16 mammal extinctions 
TABLE 1 | Disturbance events detected within the $1 \mathrm{~km}$ radius of the nest site of Egyptian vultures from 2010 to 2020.

\begin{tabular}{|c|c|c|c|c|c|c|}
\hline & \multicolumn{2}{|c|}{ Low } & \multicolumn{2}{|c|}{ Medium } & \multicolumn{2}{|c|}{ High } \\
\hline & Managed & Non-managed & Managed & Non-managed & Managed & Non-managed \\
\hline Cases & 2 & 15 & 28 & 31 & 47 & 25 \\
\hline Breeding attempts & 2 & 14 & 24 & 28 & 41 & 17 \\
\hline Fledglings & 3 & 15 & 22 & 9 & 47 & 3 \\
\hline Productivity & 1.5 & 1.07 & 0.92 & 0.32 & 1.15 & 0.18 \\
\hline
\end{tabular}

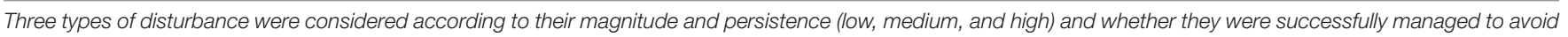

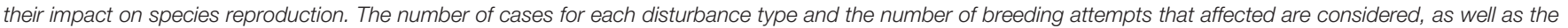
final productivity (number of fledglings/pairs that start reproduction).

TABLE 2 | Results of GLMM considering productivity (number of fledglings) of Egyptian vultures as the response variable and disturbance types (null, low, medium, and high), management ( 0 = before management, 1 = after management) as predictive variables (fixed factors) and the interaction between the two.

\begin{tabular}{|c|c|c|c|c|c|c|}
\hline & Estimate & St.error & $t$-value & $p$ & $R^{2} \mathrm{~m}(\%)$ & $R^{2} \mathrm{c}(\%)$ \\
\hline Intercept & 0.900 & 0.104 & 8.644 & $<0.001$ & 14.96 & 52.94 \\
\hline Disturbance: Low & -0.067 & 0.165 & -0.407 & 0.684 & & \\
\hline Disturbance: Medium & -1.092 & 0.169 & -6.441 & $<0.001$ & & \\
\hline Disturbance: High & -0.737 & 0.179 & -4.104 & $<0.001$ & & \\
\hline Management & -0.337 & 0.117 & -2.878 & 0.004 & & \\
\hline Disturbance: Low $\times$ management & 0.431 & 0.220 & 1.958 & 0.051 & & \\
\hline Disturbance: Medium × management & 1.108 & 0.194 & 5.694 & $<0.001$ & & \\
\hline Disturbance: High $\times$ management & 0.662 & 0.203 & 3.254 & 0.001 & & \\
\hline
\end{tabular}

The reference level for the fixed factor is the disturbance type null. The values of the estimator, standard error, the $t$-value, its corresponding $P$-value and the marginal ( $R^{2}$ $m$ ) and conditional $\left(R^{2} c\right)$ variances are shown. Significant values are highlighted in bold.

since 1993, and 9-18 bird and two to seven mammal extinctions since 2010, thus showing the effectiveness of such actions in reversing negative trends and stimulating further actions. Such studies usually require a long-term effort to evaluate their effectiveness, particularly in long-lived territorial species like vultures, whose intrinsic life-history traits (e.g., delayed maturity, long-migration, and low productivity) makes them especially vulnerable (Sergio et al., 2011; Sanz-Aguilar et al., 2017; Badia-Boher et al., 2019). Notwithstanding, these studies should account for and enhance stakeholder and manager participation to promote long-term success of management actions (Durant et al., 2019). This is particularly relevant in anthropized landscapes where conservation conflicts emerge from competing interests (Redpath et al., 2013). The management framework implemented in our study area helped to reduce uncertainty about the effects of human activities on breeding Egyptian vultures, and demonstrated how coordination between all actors (i.e., ecologists, policy makers or managers, conservation practitioners, socio-economic entities, and the general public) can alleviate conservation conflicts and ensure the persistence of threatened species.

Despite the high cost that long-term monitoring entails (Morant et al., 2020b), the evidence-based information we obtained allowed us to make critical decisions on when to monitor and when to act (Bennett et al., 2018). Our measures have been adapted through time as both human practices and species responses changed. We had previously found that even though most of the forest logging activities were conducted in winter, they still had an impact on species re-occupancy and productivity, where those territories affected by habitat changes exhibited lower re-occupancy rates and breeding success (Morant et al., 2018). Therefore, to reduce the impact in the buffer areas, we extended conservation measures in both space [from the $600 \mathrm{~m}$ first proposed by Zuberogoitia et al. (2008) to $1 \mathrm{~km}$ radius] and time (including non-breeding periods, when this migrant species is not present in our study area, Phipps et al., 2019; Morant et al., 2020b).

Conservation approaches in general have traditionally focused on large, pristine, and remote areas where sources of disturbance like those described here are rare or absent. However, in highly anthropized landscapes it is not feasible to spare large areas devoted only to conservation and there is an increasing demand of natural and semi-natural areas for recreational activities (Larson et al., 2016). Yet, these areas close to human population centers can harbor endangered species or other elements of high natural value, as in our case study. Most timber related activities and outdoor sports had never been restrained due to conservation issues before 2010 when we started applying the protocol and regulating those activities around nest sites. During the first years of management we made a communicative effort and tried to convince stakeholders and the general public about conservation issues and management measures to reduce or avoid disturbance on nesting vultures. As a consequence, most stakeholders, mainly those related to forestry, quarries and road-works, successfully adapted to conditions and limitations of conservation protocol. However, some stakeholders disagreed with our measures and regularly complained against them. What is more, there are still some outlawyers who did not agree to follow the management measures and required monitoring to prevent disturbance events. In fact, even protected areas with strict biodiversity conservation 


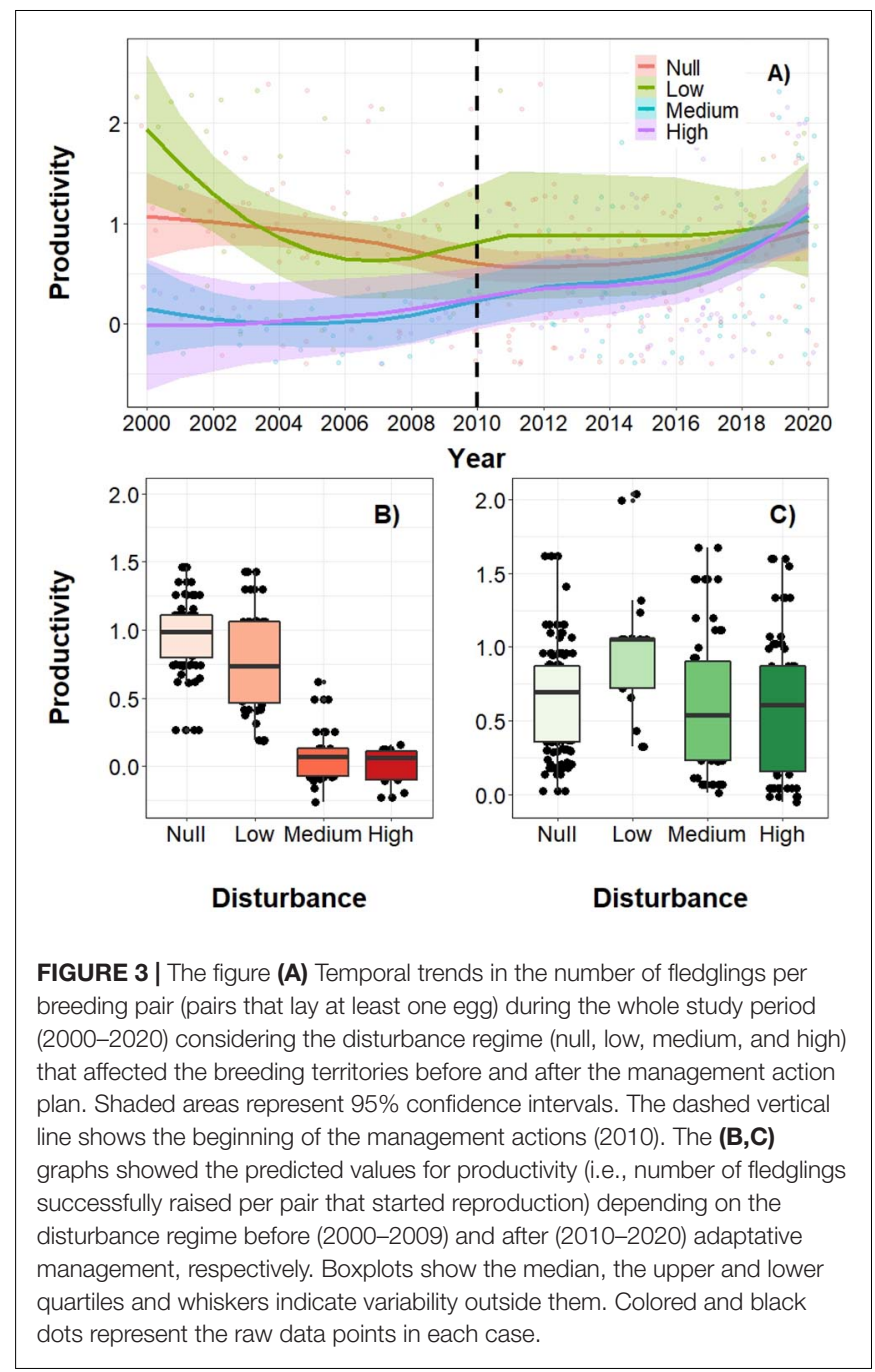

objectives suffer increasing levels of intense human pressure worldwide (Jones et al., 2018). Most of the disturbance events described in this article were detected while occurring, mainly forestry activities and outdoor sports, and BCC managers developed the managing protocol to stop them immediately. Regrettably, in some cases, we detected the activity too late. This explains why the percentage of breeding success of managed activities was not higher than we would expect.

Our results show that management measures greatly improved vital life-history values of Egyptian vultures; in fact, our study suggests that 44 fledglings may not have survived without conservation measures during the second decade of our study. However, we also must consider that those measures previously adopted by BCC, the basis of the management protocol, had a positive effect on the species conservation. During the first decade, we detected several pairs that occupied the territory, tried to breed but never achieved to lay eggs or failed during the first days. However, as we identified these problems and management measures were adapted, the number of breeding pairs increased and arrived close to the number of actual pairs (Figure 2).
TABLE 3 | Main disturbance events detected within of nest sites of Egyptian vultures during the study period (2000-2020): Forestry activities; quarry derived activities; public works; manned aerial vehicles and paragliding; outdoor sports (climbers, pedestrian, and MTB racers); recreation activities (hikers, mountain bikers, photographers, and birdwatchers); and others (illegal hunting, motorcycles, and music festivals).

\begin{tabular}{|c|c|c|c|c|c|c|}
\hline $\begin{array}{l}\text { Disturbance } \\
\text { events }\end{array}$ & $N$ & Managed & $N$ & $\begin{array}{c}\text { Nest } \\
\text { switching }\end{array}$ & Fledglings & $\begin{array}{c}\text { Breeding } \\
\text { success }\end{array}$ \\
\hline \multirow{2}{*}{$\begin{array}{l}\text { Forestry } \\
\text { activities }\end{array}$} & 56 & yes & 33 & 3 & 28 & $66.7 \%$ \\
\hline & & no & 23 & 5 & 6 & $17.4 \%$ \\
\hline \multirow[t]{2}{*}{ Outdoor sports } & 18 & yes & 5 & 1 & 4 & $60 \%$ \\
\hline & & no & 13 & 3 & 6 & $38.5 \%$ \\
\hline \multirow{2}{*}{$\begin{array}{l}\text { Quarry derived } \\
\text { activities }\end{array}$} & 14 & yes & 14 & 0 & 16 & $85.7 \%$ \\
\hline & & no & 0 & 0 & 0 & $0 \%$ \\
\hline \multirow[t]{2}{*}{ Public works } & 14 & yes & 12 & 1 & 13 & $75 \%$ \\
\hline & & no & 2 & 0 & 0 & $0 \%$ \\
\hline \multirow{2}{*}{$\begin{array}{l}\text { Recreation } \\
\text { activities }\end{array}$} & 13 & yes & 1 & 0 & 1 & $100 \%$ \\
\hline & & no & 12 & 3 & 8 & $50 \%$ \\
\hline \multirow{2}{*}{$\begin{array}{l}\text { Manned aerial } \\
\text { vehicles and } \\
\text { paragliding }\end{array}$} & 6 & yes & 2 & 0 & 1 & $50 \%$ \\
\hline & & no & 4 & 0 & 3 & $50 \%$ \\
\hline \multirow[t]{2}{*}{ Others } & 17 & yes & 7 & 0 & 4 & $57.1 \%$ \\
\hline & & no & 10 & 1 & 5 & $40 \%$ \\
\hline
\end{tabular}

The table shows the number of disturbance events and how many of them were managed or not, and in each case the number of pairs that switched to other nest, the number of fledglings raised and the breeding success (percentage of the number of successfully pairs/number of pairs that started reproduction).

This is a critical outcome given the delayed maturation, lowproductivity and strong fidelity to the breeding site of the species (Sanz-Aguilar et al., 2017). For instance, Serrano et al. (2021) showed that natal dispersal distances of Egyptian vultures were negatively related to natal breeding population density and population trends (social cues). Hence, increasing the breeding success with low adult mortality rate, as our case (Zuberogoitia et al., 2009), would help to increase the viability of Egyptian vulture populations, not only in the target area but also in the neighboring regions since they play an essential role in demographic processes such as source-sink dynamics (e.g., Hernández-Matias et al., 2013; Lieury et al., 2016; Weegman et al., 2016; Sanz-Aguilar et al., 2017; Soriano-Redondo et al., 2019).

Conservation programs that succeed in reducing and palliating the main threats to target species and identify and engage with all stakeholders to implement solutions, particularly in areas of conflict with high human density, should be regarded effective. Management measures accompanied by effective participation among stakeholders improve relationships, increase trust, and reduce conflict (e.g., Reed, 2008). Recognizing the important role of each and every actor is crucial toward constructing transparent and trustful relationship among interested parties (Redpath et al., 2013). For example, a key way for conservation managers to access relevant and updated scientific knowledge is through direct contact with ecologists, who conduct field research within the sites they manage 
(Durant et al., 2019). Similarly, ecologists should realize that decision-makers have to deal with multiple competing and often conflicting interests (e.g., species conservation in areas of highvalue resource extraction), and sometimes decisions on species conservation are dictated by higher political interests rather than a lack of knowledge about the system in question (Cook et al., 2013; Redpath et al., 2015). In our case, we were able to construct a collaborative network by targeting all social dimensions of the conflict, and promoting the mutual-understanding of each party's needs. Encouraging the involvement in species conservation of all relevant actors alleviated conflicts and paved the road toward measures that could be objectively considered balanced and successful in terms of conservation and socio-economic interests. We are far from a final solution that fully satisfies all stakeholders (Redpath et al., 2013, 2017), but our study showed that humanwildlife coexistence is still possible in an increasingly crowded and human-modified world, while considering and maintaining the livelihoods and well-being of all actors involved.

\section{CONCLUDING REMARKS}

World human population is quickly increasing, and it is expected to reach $c a$. 11 billion in $2100^{2}$. This means that virtually all the areas considered pristine or unaltered will be occupied in one way or another as human requirements (e.g., resources, space) increase and those already occupied may be more intensively exploited (Bowler et al., 2020). It is expected that, in a few decades, traditional grazing activities will be abandoned in large areas of the European continent and, while some regions evolve toward rewilding processes affecting the scavenger guild structure and function (García-Barón et al., 2018; Martín-Díaz et al., 2020), others will continue the intensive occupation and use of land, which may impose potentially greater impacts on natural systems (e.g., agricultural intensification, growth of urban areas; Deinet et al., 2013; Navarro and Pereira, 2015). Under these new scenarios, conservation conflicts in anthropized areas are expected to increase. In this paper, we show that management actions are essential for the coexistence between humans and threatened species in anthropized areas. Approaches like ours could be complemented with other measures such as campaigns to increase social awareness and behavioral change amongst overall population. Such measures could help to prevent some of the human pressures addressed in this paper (e.g.,

${ }^{2}$ https://ourworldindata.org/future-population-growth

\section{REFERENCES}

Aresu, M. A., Rotta, A., Fozzi, A., Campus, A., Muzzeddu, M., Secci, D., et al. (2020). Assessing the effects of different management scenarios on the conservation of small island vulture populations. Bird Conserv. Int. 31, 1-18. doi: 10.1017/S0959270920000040

Arrondo, E., Sanz-Aguilar, A., Pérez-García, J. M., Cortés-Avizanda, A., SánchezZapata, J. A., and Donázar, J. A. (2020). Landscape anthropization shapes the survival of a top avian scavenger. Biodivers. Conserv. 29, 1411-1425.

Badia-Boher, J. A., Sanz-Aguilar, A., de la Riva, M., Gangoso, L., van Overveld, T., García-Alfonso, M., et al. (2019). Evaluating European LIFE conservation projects: imprevements in survival of an endangered vulture. J. Appl. Ecol. 56, 1210-1219. doi: 10.1111/1365-2664.13350 recreational activities in breeding areas of Egyptian vultures; Badia-Boher et al., 2019; Salazar et al., 2019) that are generally difficult to detect and manage. Taken together, accounting for all these factors can promote the persistence of Egyptian vultures and other raptors in human-dominated lands and, eventually, favor long-term conservation success.

\section{DATA AVAILABILITY STATEMENT}

The raw data supporting the conclusions of this article will be made available by the authors, without undue reservation.

\section{ETHICS STATEMENT}

All procedures were carried out in accordance with the recommendations and regulations.

\section{AUTHOR CONTRIBUTIONS}

IZ: study design and data analyses. IZ, JM, JG-O, JMa, and JZ: writing. IZ, JM, ML, JR, IA, CC, ED, FM, AG, JP, GV, BL, and II: field work and data collection. All authors contributed to the article and approved the submitted version.

\section{FUNDING}

The Biscay County Council Environment Department partially supported the fieldwork and issued the licenses to work with the species. JM was supported by a Basque Government Predoctoral grant (PRE_2018_2_0112).

\section{ACKNOWLEDGMENTS}

We thank Lander Astorkia, Iñaki Castillo, Gorka Burgos, Agurtzane Iraeta, Ainara Azkona, Julen Zuberogoitia, Marco Pecoraro, Mikel Larrea, Karmele Gallastegi, and Maialen Azpillaga for their field assistance. The Environment Department of the Biscay County Council partially supported the fieldwork and issued the licenses to work with this species. We greatly appreciate the comments from reviewers including Joan Real which substantially improved our previous draft.

Bates, D., Maechler, M., and Bolker, B. (2012). Ime4: Linear Mixed-Effects Models Using S4 Classes. R Package Version 0.999999-0. Available online at: http:// CRAN.R-project.org/package=lme4 (accessed October 28, 2020)

Bennett, J. R., Maxwell, S. L., Martin, A. E., Chadès, I., Fahrig, L., and Gilbert, B. (2018). When to monitor and when to act: value of information theory for multiple management units and limited budgets. J. Appl. Ecol. 55, 2102-2113. doi: 10.1111/1365-2664.13132

BirdLife International (2020). IUCN Red List for Birds. Available online at: http: //www.birdlife.org (accessed October 28, 2020)

Bizkaia (2021a). Decreto Foral 103/2018, de 24 de julio, de la Diputacion Foral de Bizkaia, por el que se Regula la Autorización para la Celebración de Pruebas Deportivas Colectivas en Espacios Naturales Protegidos $y$ Montes del Territorio Histórico de Bizkaia. Available online at: 
https://www.bizkaia.eus/Kultura/kirolak/Kirolbide_Bizkaia/publikoa/visor_ Legislacion.asp?Tem_Codigo $=2260 \& \operatorname{Cod}=1839 \&$ anio $=2014 \&$ Idioma $=C A$ (accessed January 5, 2021)

Bizkaia (2021b). Decreto Foral 60/2019, de 21 de Mayo, de la Diputación Foral de Bizkaia, por el que se Regula la Autorización para la Celebración de Pruebas Deportivas Colectivas en Espacios Naturales Protegidos y para el caso de Afección a Especies Amenazadas del Territorio Histórico de Bizkaia. Available online at: http://apps.bizkaia.eus/BT00/SumarioUltimoServlet?fecha= 20190523\&numero $=97 \&$ primero $=0$ \&referenciaBoletin $=$ BOB- 2019a097.pdf $\&$ sumarioBoletin $=$ BOB-2019a097.pdf\&impresion $=0$ \&idi=es\&origen $=$ ultimo (accessed January 5, 2021)

Bizkaia (2021c). Decreto Foral 83/2015, de 15 de Junio, de la Diputación Foral de Bizkaia por el que se Aprueba el Plan Conjunto de Gestión de las aves Necrófagas de Interés Comunitario de la Comunidad Autónoma del País Vasco. Available online at: https://www.bizkaia.eus/home2/Temas/DetalleTema.asp?Tem Codigo $=4344 \&$ idioma $=$ CA\&dpto_biz $=2 \&$ codpath_biz $=2 \% 7 C 4344 \quad$ (accessed January 5, 2021)

Blackwell, B. F., DeVault, T. L., Fernández-Juricic, E., Gese, E. M., Gilbert-Norton, L., and Breck, S. W. (2016). No single solution: application of behavioural principles in mitigating human-wildlife conflict. Anim. Behav. 120, 245-254. doi: 10.1016/j.anbehav.2016.07.013

Bolam, F. C., Mair, L., Angelico, M., Brooks, T. M., Burgman, M., Hermes, C., et al. (2020). How many bird and mammal extinctions has recent conservation action prevented? Conserv. Lett. 14:e12762. doi: 10.1111/conl.12762

Bolker, B. M., Brooks, M. E., Clark, C. J., Geange, S. W., Poulsen, J. R., Stevens, M. H. H., et al. (2009). Generalized linear mixed models: a practical guide for ecology and evolution. Trends Ecol. Evol. 24, 127-135. doi: 10.1016/j.tree.2008. 10.008

Bowler, D. E., Bjorkman, A. D., Dornelas, M., Myers-Smith, I. H., Navarro, L. M., Niamir, A., et al. (2020). Mapping human pressures on biodiversity across the planet uncovers anthropogenic threat complexes. People Nat. 2, 380-394. doi: $10.1002 /$ pan 3.10071

Cook, C. N., Mascia, M. B., Schwartz, M. W., Possingham, H. P., and Fuller, R. A. (2013). Achieving conservation science that bridges the knowledge-action boundary. Conserv. Biol. 27, 669-678. doi: 10.1111/cobi.12050

Defourny, P., Santoro, M., Kirches, G., Wevers, J., Boettcher, M., Brockmann, C., et al. (2017). Land Cover CCI: Product User Guide Version 2.0. Available online at: http://maps.elie.ucl.ac.be/CCI/viewer/download/ESACCI-LC-PUGv2.5.pdf (accessed November 15, 2021)

Deinet, S., Ieronymidou, C., McRae, L., Burfield, I. J., Foppen, R. P., Collen, B., et al. (2013). Wildife Comeback in Europe: The Recovery of Selected Mammal and Bird Species. Final Report to Rewilding Europe by ZSL, BirdLife International and the European Bird Census Council. London: ZSL.

Donázar, J. A. (1993). Los Buitres Ibéricos: Biología y Conservación. Madrid: JM Reyero.

Donázar, J. A., Palacios, C. J., Gangoso, L., Ceballos, O., González, M. J., and Horaldo, F. (2002). Conservation status and limiting factors in the endangered population of Egyptian vulture (Neophron percnopterus) in the Canary Island. Biol. Conserv. 107, 89-97. doi: 10.1016/s0006-3207(02)00049-6

Dreiss, L. M., Hessenauer, J.-M., Nathan, L. R., OñConnor, K. M., Liberati, M. R., Kloster, D. P., et al. (2017). Adaptative management as an effective strategy: interdisciplinary perceptions for natural resources management. Environ. Manage. 59, 218-229. doi: 10.1007/s00267-016-0785-0

Durant, S. M., Groom, R., Kuloba, B., Samna, A., Muzuma, U., Gadimang, P., et al. (2019). Bridging the divide between scientists and decision-makers: how behavioural ecologists can increase the conservation impact of their research? Phil. Trans. R. Soc. B 374:20190011. doi: 10.1098/rstb.2019.0011

Duriez, O., Descaves, S., Gallais, R., Neouza, R., Fluhr, J., and Decante, F. (2019). Vultures attacking livestock: a problem of vulture behavioral change or farmers's perception? Bird Conserv. Int. 29, 1-17. doi: 10.4314/vulnew.v77i1.c

Efrat, R., Hatzofe, O., and Berger-Tal, O. (2020). Translating large-scale prioritization models for vultures to local-scale decision-making: response to Santangeli et al., 2019. Conserv. Biol. 34, 1305-1307. doi: 10.1111/cobi.13557

Euskadi.eus (2019). El Bosque Vasco en Cifras 2019. Available online at: https://www.euskadi.eus/contenidos/informacion/mapa_forestal_2019/es_ agripes/adjuntos/El-bosque-vasco-en-cifras-2019.pdf (accessed January 5, 2021)

Euskalmet.eus (2021). Avisos y Alertas Meteorológicas. Available online at: https://www.euskalmet.euskadi.eus/s07-5853x/es/meteorologia/home.apl?e=5 (accessed January 5, 2021)
Eustat.eus (2020). Población. Available online at: https://www.eustat.eus/ estadisticas/tema_159/opt_0/ti_poblacion/temas.html (accessed January 5, 2021)

Ferguson-Lees, J., and Christie, D. A. (2001). Raptors of the World. New York, NY: Houghton Mifflin Company.

Ferrier, S., and Wintle, B. A. (2009). "Quantitative approaches to spatial conservation prioritization: matching the solution to the need," in Spatial Conservation Prioritization, Quantitative Methods and Computational Tools, eds A. Moilanen, K. A. Wilson, and H. P. Possingham (Oxford: Oxford University Press), 1-15.

García-Barón, I., Cortés-Avizanda, A., Verburg, P. H., Marques, T. A., MorenoOpo, R., Pereira, H. M., et al. (2018). How to fit the distribution of apex scavengers into land-abandonment scenarios? The Cinereous vulture in the Mediterranean biome. Divers. Distrib. 24, 1018-1031. doi: 10.1111/ddi.12743

Gaynor, K. M., Hojnowski, C. E., Carter, N. H., and Brashares, J. S. (2018). The influence of human disturbance on wildlife nocturnality. Science 360 , 1232-1235. doi: 10.1126/science.aar7121

Goode, K., and Rey, K. (2019). ggResidpanel: Panels and Interactive Versions of Diagnostic Plots using 'ggplot2'. R Package Version 0.3.0. Available online at: https://CRAN.R-project.org/package=ggResidpanel (accessed October 5, 2020)

Hernández-Matias, A., Real, J., Moleon, M., Palma, L., Sánchez-Zapata, J. A., Pradel, R., et al. (2013). From local monitoring to a broad-scale viability assessment: a case study for the Bonelli's Eagle Aquila fasciata in western Europe. Ecol. Monogr. 83, 239-261. doi: 10.1890/12-1248.1

Jones, K. R., Venter, O., Fuller, R. A., Allan, J. R., Maxwell, S. L., Negret, P. J., et al. (2018). One-third of global protected land is under intense human pressure. Science 360, 788-791. doi: 10.1126/science.aap9565

Larson, C. L., Reed, S. E., Merenlender, A. M., and Crooks, K. R. (2016). Effects of recreation on animals revealed as widespread through a global systematic review. PLoS One 11:e0167259. doi: 10.1371/journal.pone.0167259

Lefcheck, J. S. (2015). piecewiseSEM: piecewise structural equation modelling in $\mathrm{r}$ for ecology, evolution, and systematics. Methods Ecol. Evol. 7, 573-579. doi: 10.1111/2041-210x.12512

Lieury, N., Besnard, A., Ponchon, C., Ravayrol, A., and Millon, A. (2016). Geographically isolated but demographically connected: immigration supports efficient conservation actions in the recovery of a range-margin population of the Bonelli's eagle in France. Biol. Conserv. 195, 272-278. doi: 10.1016/j.biocon. 2016.01.011

Margalida, A., Campion, D., and Donazar, J. A. (2014). Vultures vs livestock: conservation relationships in an emerging conflict between humans and wildlife. Oryx 48, 172-176. doi: 10.1017/s0030605312000889

Martín-Díaz, P., Cortés-Avizanda, A., Serrano, D., Arrondo, E., Sánchez-Zapata, J. A., and Donázar, J. A. (2020). Rewilding processes shape the use of Mediterranean landscapes by an avian top scavenger. Sci. Rep. 10:2853.

McCarthy, M. A., and Possingham, H. P. (2007). Active adaptive management for conservation. Conserv. Biol. 21, 956-963. doi: 10.1111/j.1523-1739.2007.00677.x

McClure, C. J. W., Westrip, J. R. S., Johnson, J. A., Schulwitz, S. E., Virani, M. Z., Davies, R., et al. (2018). State of the world's raptors: distributions, threats, and conservation recommendations. Biol. Conserv. 227, 390-402. doi: 10.1016/j. biocon.2018.08.012

McClure, C. J., and Rolek, B. W. (2020). Relative conservation status of bird orders with special attention to raptors. Front. Ecol. Evol. 8:593941. doi: 10.3389/fevo. 2020.593941

McDonald, T. L., and White, G. C. (2010). A comparison of regression models for small counts. J. Wildlife Manage. 74, 514-521. doi: 10.2193/2009-270

Morant, J. M., Abad-Gómez, J. M., Álvarez, T., Sánchez, A., Zuberogoitia, I., and López-López, P. (2020a). Movements and structure of a globally endangered scavenger wintering in south-west Europe. Sci. Rep. 10:17690. doi: 10.1038/ s41598-020-74333-0

Morant, J. M., González-Oreja, J. A., Martínez, J. E., López-López, P., and Zuberogoitia, I. (2020b). Applying economic and ecological criteria to design cost-effective monitoring for elusive species. Ecol. Indic. 115:106366. doi: 10. 1016/j.ecolind.2020.106366

Morant, J., López-López, P., and Zuberogoitia, I. (2019). Parental investment asymmetries of a globally endangered scavenger: unravelling the role of gender, weather conditions and stage of the nesting cycle. Bird Stud. 66, 329-341. doi: 10.1080/00063657.2019.1688251

Morant, J., Zabala, J., Martínez, J. E., and Zuberogoitia, I. (2018). Out of sight, out of mind? Testing the effects of overwinter habitat alterations on breeding 
territories of a migratory endangered species. Anim. Conserv. 21, 465-473. doi: $10.1111 /$ acv.12412

Navarro, L. M., and Pereira, H. M. (2015). "Rewilding abandoned landscapes in Europe," in Rewilding European Landscapes, eds H. M. Pereira and L. M. Navarro (Basel: Springer International Publishing).

Newbold, T., Hudson, L. N., Hill, S. L., Contu, S., Lysenko, I., Senior, R. A., et al. (2015). Global effects of land use on local terrestrial biodiversity. Nature 520, $45-50$.

O’Bryan, C. J., Allan, J. R., Holden, M., Sanderson, C., Venter, O., Di Marco, M., et al. (2020). Intense human pressure is widespread across terrestrial vertebrate ranges. Glob. Ecol. Conserv. 21:e00882. doi: 10.1016/j.gecco.2019.e00882

Ogada, D. L., Torchin, M. E., Kinnaird, M. F., and Ezenwa, V. O. (2012). Effects of vulture declines on facultative scavengers and potential implications for mammalian disease transmission. Conserv. Biol. 26, 453-460. doi: 10.1111/j. 1523-1739.2012.01827.x

Ogada, D., Shaw, P., Beyers, R. L., Buij, R., Murn, C., Thiollay, J. M., et al. (2016). Another continental vulture crisis: Africa's vultures collapsing toward extinction. Conserv. Lett. 9, 89-97. doi: 10.1111/conl.12182

Olea, P. P., and Mateo-Tomás, P. (2014). Living in risky landscapes: delineating management units in multithreat environments for effective species conservation. J. Appl. Ecol. 51, 42-52. doi: 10.1111/1365-2664.12176

Phipps, W. L., López-López, P., Buechley, E., Oppel, S., Álvarez, E., Arkumarev, V., et al. (2019). Spatial and temporal variability in migration of a soaring raptor across three continents. Front. Ecol. Evol. 7:323. doi: 10.3389/fevo.2019. 00323

Plaza, P. I., Martínez-López, E., and Lambertucci, S. A. (2019). The perfect threat: pesticides and vultures. Sci. Total Environ. 687, 1207-1218. doi: 10.1016/j. scitotenv.2019.06.160

Redpath, S. M., Gutiérrez, R. J., Wood, K. A., and Young, J. C. (eds) (2015). Conflicts in Conservation: Navigating Towards Solutions. Cambridge: Cambridge University Press.

Redpath, S. M., Linnell, J. D., Festa-Bianchet, M., Boitani, L., Bunnefeld, N., Dickman, A., et al. (2017). Don't forget to look down-collaborative approaches to predator conservation. Biol. Rev. 92, 2157-2163. doi: 10.1111/brv.12326

Redpath, S. M., Young, J., Evely, A., Adams, W. M., Sutherland, W. J., Whitehouse, A., et al. (2013). Understanding and managing conservation conflicts. Trends Ecol. Evol. 28, 100-109.

Reed, M. S. (2008). Stakeholder participation for environmental management: a literature review. Biol. Conserv. 141, 2417-2431. doi: 10.1016/j.biocon.2008.07. 014

Richardson, S., Mill, A. C., Davis, D., Jam, D., and Ward, A. I. (2020). A systematic review of adaptive wildlife management for the control of invasive, non-native mammals, and other human-wildlife conflicts. Mammal Rev. 50, 147-156. doi: $10.1111 / \mathrm{mam} .12182$

Riggio, J., Baillie, J. E., Brumby, S., Ellis, E., Kennedy, C. M., Oakleaf, J. R., et al. (2020). Global human influence maps reveal clear opportunities in conserving Earth's remaining intact terrestrial ecosystems. Glob. Chang. Biol. 26, 43444356. doi: 10.1111/gcb.15109

Ripple, W. J., Estes, J. A., Beschta, R. L., Wilmers, C. C., Ritchie, E. G., Hebblewhite, M., et al. (2014). Status and ecological effects of the world's largest carnivores. Science 343:1241484. doi: 10.1126/science.1241484

Runge, M. C. (2011). Adaptive management for threatened and endangered species. J. Fish Wild Manag. 2, 220-233. doi: 10.3996/082011-jfwm-045

Salazar, G., Mills, M., and Veríssimo, D. (2019). Qualitative impact evaluation of a social marketing campaign for conservation. Conserv. Biol. 33, 634-644. doi: $10.1111 /$ cobi.13218

Sanders, D., Frago, E., Kehoe, R., Patterson, C., and Gaston, K. J. (2020). A metaanalysis of biological impacts of artificial light at night. Nat. Ecol. Evol. 5, 74-81. doi: 10.1038/s41559-020-01322-x

Santangeli, A., Girardello, M., Buechley, E., Botha, A., Di Minin, E., and Moilanen, A. (2019). Priority areas for conservation of Old World vultures. Conserv. Biol. 33, 1056-1065. doi: $10.1111 /$ cobi.13282

Sanz-Aguilar, A., Cortés-Avizanda, A., Serrano, D., Blanco, G., Ceballos, O., Grande, J. M., et al. (2017). Sex-and age-dependent patterns of survival and breeding success in a long-lived endangered avian scavenger. Sci. Rep. 7:40204.

Sergio, F., Tavecchia, G., Blas, J., López, L., Tanferna, A., and Hiraldo, F. (2011). Variation in age-structured vital rates of a long-lived raptor: implications for population growth. Basic Appl. Ecol. 12, 107-115. doi: 10.1016/j.baae.2010.11. 004
Serrano, D., Cortés-Avizanza, A., Zuberogoitia, I., Blanco, G., Benítez, J. R., Ponchon, C., et al. (2021). Phenotype- and environmental-dependent natal dispersal in a long-lived territorial vulture. Sci. Rep. 11:5424. doi: 10.1038/ s41598-021-84811-8

Singmann, H., Bolker, B., Westfall, J., Aust, F., and Ben-Shachar, M. S. (2021). afex: Analysis of Factorial Experiments. R Package Version 0.28-1. Available online at: https://CRAN.R-project.org/package=afex (accessed November 15, 2020)

Soriano-Redondo, A., Hilton, G. M., Gutiérrez, J. S., Lock, L., Stanbury, A., Votier, S. C., et al. (2019). The role of immigration and reinforcement in the population dynamics of a long-lived bird: implications for the conservation of threatened species. Anim. Conserv. 22, 49-58. doi: 10.1111/acv.12434

UNEP-WCMC, IUCN, and NGS (2019). Protected Planet Live Report 2019. Cambridge: UNEP-WCMC.

van Eeden, L. M., Crowther, M. S., Dickman, C. R., Macdonald, D. W., Ripple, W. J., Ritchie, E. G., et al. (2018). Managing conflict between large carnivores and livestock. Conserv. Biol. 32, 26-34. doi: 10.1111/cobi.12959

Venter, O., Sanderson, E. W., Magrach, A., Allan, J. R., Beher, J., Jones, K. R., et al. (2016). Sixteen years of change in the global terrestrial human footprint and implications for biodiversity conservation. Nat. Commun. 7:12558.

Web.bizkaia.eus (2010). Climbing Management in Bizkaia and Urkiola. Available online at: https://www.bizkaia.eus/home2/Temas/DetalleTema.asp?Tem_ Codigo $=6386$ andidioma $=$ CAanddpto_biz $=2$ andcodpath_biz $=2 \% 7 C 7309 \%$ 7C6386 (accessed October 13, 2020)

Weegman, M. D., Bearhop, S., Fox, A. D., Hilton, G. M., Walsh, A. J., McDonald, J. L., et al. (2016). Integrated population modelling reveals a perceived source to be a cryptic sink. J Anim. Ecol. 85, 467-475. doi: 10.1111/1365-2656. 12481

Wickham, H. (2016). ggplot2: Elegant Graphics for Data Analysis. New York: Springer-Verlag.

Wilson, M. W., Ridlon, A. D., Gaynor, K. M., Gaines, S. D., Stier, A. C., and Halpern, B. S. (2020). Ecological impacts of human-induced animal behaviour change. Ecol. Lett. 23, 1522-1536. doi: 10.1111/ele.13571

Zuberogoitia, I., Álvarez, K., Olano, M., Rodríguez, A. F., and Arambarri, R. (2009). "Avian scavenger populations in the Basque Country: status, distribution and breeding parameters," in Vultures, Feeding Stations and Sanitary Legislation: A Conflict and its Consequences from the Perspectiva of Conservation Biology. Monograph Munibe, Vol. 29, eds J. A. Donázar, A. Margalida, and D. Campion (Donostia-San Sebastian: Sociedad de Ciencias Aranzadi), 34-65.

Zuberogoitia, I., Zabala, J., Martínez, J. A., Martínez, J. E., and Azkona, A. (2008). Effects of human activities on Egyptian vulture breeding success. Anim. Conserv. 11, 313-320. doi: 10.1111/j.1469-1795.2008.00184.x

Zuberogoitia, I., Zabala, J., Martínez, J. E., González-Oreja, J. A., and López-López, P. (2014). Effective conservation measures to mitigate the impact of human disturbances on the endangered Egyptian vulture. Anim. Conserv. 17, 410-418. doi: $10.1111 /$ acv.12107

Conflict of Interest: IZ was employed by company Estudios Medioambientales Icarus S.L. C. JMa was employed by company Bonellis Eagle Study and Conservation Group.

The remaining authors declare that the research was conducted in the absence of any commercial or financial relationships that could be construed as a potential conflict of interest.

Publisher's Note: All claims expressed in this article are solely those of the authors and do not necessarily represent those of their affiliated organizations, or those of the publisher, the editors and the reviewers. Any product that may be evaluated in this article, or claim that may be made by its manufacturer, is not guaranteed or endorsed by the publisher.

Copyright $\odot 2021$ Zuberogoitia, Morant, González-Oreja, Martínez, Larrinoa, Ruiz, Aginako, Cinos, Díaz, Martínez, Galarza, Pérez de Ana, Vacas, Lardizabal, Iriarte and Zabala. This is an open-access article distributed under the terms of the Creative Commons Attribution License (CC BY). The use, distribution or reproduction in other forums is permitted, provided the original author(s) and the copyright owner(s) are credited and that the original publication in this journal is cited, in accordance with accepted academic practice. No use, distribution or reproduction is permitted which does not comply with these terms. 